\title{
Economic Sustainability of a New Born State
}

\author{
Afrim Hoti, PhD \\ afrimhoti@hotmail.com \\ ILIRIA College Professor, International Relations and Diplomacy Faculty
}

Fitore Bekteshi, BA

fitore.bekteshi@gmail.com

Original Member of the Youth Council of the U.S. Embassy Prishtina

ILIRIA University College Associate

\section{Abstract}

Sustainable development is the concept of a relationship between economic growth and the environment ${ }^{1}$ and especially when it comes to a new born country, such as Kosovo. It is naturally important for Kosovo as country, which used to be for a long time with no adequate attention in terms of the economic development under the Yugoslavian political, legal and economic development. Republic of Kosovo is among the richest countries in Europe and wider, seen on the perspective of natural and human resources as well as for geographical position. Nevertheless, the country never had the opportunity to develop itself, using its own resources. Internationally, based on Universal Declaration of Human Rights, International Covenants on Civil and Political Rights as well as the Economic, Social and Cultural Rights, when speaking for selfdetermination, apart from politics, these documents include the exclusive rights of nations to develop research as well as to orient its country economic resources and economic agenda. Therefore paper aims to present facts on the implication of domestic and international politics in relation to the economic development of a new born country. The analysis will be focused on the policies of Kosovo, as well as activities undertaken in the direction of building an attracting environment in Kosovo for Foreign Direct and Indirect Investments as well as to incite local and international initiatives for business, aiming the general economic growth and the economical sustainability of the state.

Keywords: Economy, State, Stability, Growth, Kosovo, Sustainability, Development, Investments, Businesses, Natural Resources.

\section{Introduction}

Transitioning from a centrally planned economy to a more market-based economy, Kosovo has been privatizing many of its state-owned assets. The nation has opened its borders to trade and investment, with services and manufacturing accounting for a large majority of economic activity. Parliamentary elections in June 2014 produced political deadlock, further hampering progress on economic reform. Half of Kosovo's population is under 25, unemployment remains high at 35 percent, and informal networks and transactions remain a large portion of the economy. Despite progress since independence, institutional capacity remains weak, and remittances account for around 15 percent of GDP. A truly independent judiciary is not yet a reality. Intrusive bureaucracy and costly registration procedures reflect a history of central planning. Greater political commitment is needed to implement the significant reforms necessary to jump-start the economy and stamp out corruption. ${ }^{2}$

\footnotetext{
${ }^{1}$ The Economics of Sustainable Development, Sisay Afera, W.E. Upjohn Institute for Employment Research Kalamazoo, Michigan, 2005, pg. 1

2015 Index of Economic Freedom Brochure, March 2015, pg. 1, Available on:
} 
On the other hand, many international instruments and conventions once speaking for the self-determination, they refer to the broader meaning of this principle. Apart from the politics, such principle includes also the right of a state to address and lead the economic aspects and entire economic development and economic sustainability. Such rights are entitled to a state, as well as to individuals in personam with no distinction as per race, color, sex, religion and other views. Article 25, paragraph 1, of the Universal Declaration of Human Rights refers to some fundamental human rights related to the aspects of self-determination. These fundamentals are that everyone has the right to a standard of living adequate for the health and well-being of himself and of his family, including food, clothing, housing and medical care and necessary social services, and the right to security in the event of unemployment, sickness, disability, widowhood, old age or other lack of livelihood in circumstances beyond his control ${ }^{1}$. Moreover, these rights also mentioned in other international instruments, such is International Covenant on Civil and Political Rights, where, among others, emphasize that "All peoples have the right of self-determination. By virtue of that right they freely determine their political status and freely pursue their economic, social and cultural development2. All peoples may, for their own ends, freely dispose of their natural wealth and resources without prejudice to any obligations arising out of international economic co-operation, based upon the principle of mutual benefit, and international law. In no case may a people be deprived of its own means of subsistence ${ }^{3}$. It means that the country's right to self-determination is not limited exclusively into the political agenda. More than this, country's right to self-determination as it has been stipulated into the convention, means the country's right to lead, administer and free usage of its own natural resources.

The autonomy on country's self-exploitation and self-determination, as regards of its own resources, is also determined by the International Covenant on Economic, Social and Cultural Rights, which moreover stipulates that "Each State Party to the present Covenant undertakes to take steps, individually and through international assistance and co-operation, especially economic and technical, to the maximum of its available resources, with a view to achieving progressively the full realization of the rights recognized in the present Covenant by all appropriate means, including particularly the adoption of legislative measures"4.

\section{Globalization: Kosovo as new born state}

Despite the highly favorable views that most researchers in the academic community and in the international development organizations hold on the globalization process and its impact on developing countries, and notwithstanding the strong support of the empirical evidence of the benefits that many developing countries have derived from their integration with the global economy, the backlash against globalization continues unabated. An online debate on "Globalization and Poverty" organized by the World Bank Development Forum in mid-2000 echoed the loud and often very aggressive protests against globalization that erupted ${ }^{5}$ worldwide. Globalization effects of economy might be seen especially in the small and newborn countries as it is the case of Kosovo ${ }^{6}$ where the state cannot afford the adoption of global trends due to lack of proper instruments and available resources, in terms of technical and technological capacities, competition of multinational companies and so on. In these countries their respective governments must undertake specific steps or measures to create an environment where trends of globalization can be properly fit. These considerations led to the argument that in these countries the government must take active measures to secure the livelihood of the poor, even if these measures may restrict the free market and diminish the country's growth prospects. The counterargument asserted that, by reducing the country's rate of growth, the government might in fact defeat the long-term goal of reducing poverty?

http://www.heritage.org/index/pdf/2015/countries/kosovo.pdf [Accessed: 21 March, 2015]

1 Universal Declaration of Human Rights

2 International Covenant on Civil and Political Rights

$3 \mathrm{lbid}$

${ }^{4}$ International Covenant on Economic, Social and Cultural Rights

${ }^{5}$ David Bigman, Ed. "Globalization and the developing countries. Emerging strategies for rural development and poverty alleviations". $\mathrm{CABI}$ publishing in association with the International Service for National Agricultural Research. 2002. pg 27

${ }^{6}$ According to 2015 Index of Economic Freedom Kosovo's economy is not graded in the 2015 Index due to insufficient data. Facets of economic freedom for which data are available have been scored individually. Kosovo will receive an overall economic freedom score and ranking in future editions as more reliable information becomes available.

7 lbid. pg 34 . 
The role of international community especially of the international financial mechanisms is crucial, as regards to the support on building economy and national economic infrastructures of developing countries as well as developed ones. Such model is the IMF Policy Programme, a program established on case of East Asian crisis, as the financial crisis deepened in East Asia and more and more countries became involved, the IMF assembled large financial packages to bail out the affected countries. However, this aid was available only in return for draconian conditionality. Apart from their usual policies of demand restraint (cuts in money supply, high interest rates, fiscal retrenchment, etc.) the IMF went further. It demanded far-reaching changes in the economic and social systems of these countries. These changes included still more liberalization of the financial sector (including permitting hostile take-overs of domestic firms by nonresidents); changes in the system of corporate governance, in labor laws, in government business relations, and in competition policy. Such measures were insisted on because it was believed (erroneously as we have seen above) that the root cause of the crisis was the 'dirigiste' institutional structures and policies of these countries. The IMF policy programmes for the affected Asian countries may be faulted for a number of important reasons ${ }^{1}$.

In order for the economy of the country of Kosovo to suitably become part of the globalization agenda, it ought for it to create some specific key pillars which would assist on assuring the achievement of such goal. These are the following areas:

\subsection{Political Stability and Rule of Law}

Political stability and rule of law enforcement is an issue which is of a great importance when it refers to globalization process as well as sustainability of a new born state and all states in general. This, due to the fact that corruption and political instability, surely leads toward mistrust and indifference of international firms and corporations to create business links with countries in general and within this perspective of Kosovo economy. A theory which better explains this says that Corruption flouts rules of fairness and gives some people advantages that others don't have. Corruption is persistent; there is little evidence that countries can escape the curse of corruption easily - or at all. Instead of focusing on institutional reform, Eric M. Uslaner suggests that the roots of corruption lie in economic and legal inequality, low levels of generalized trust (which are not readily changed), and poor policy choices (which may be more likely to change). Economic inequality provides a fertile breeding ground for corruption, which, in turn, leads to further inequalities. ${ }^{2}$ The author also points that just as corruption is persistent, inequality and trust do not change much over time, cross-national aggregate analyses. $\mathrm{He}$ argues that high inequality leads to low trust and high corruption, and then to more inequality - an inequality trap - and identifies direct linkages between inequality and trust in surveys of the mass public and elites in transition countries. ${ }^{3}$ Seen in this perspective Kosovo faces numerous challenges. The rule of law in Kosovo, including judicial independence, and limited results in the fight against organized crime and corruption remains a major concern. ${ }^{4}$ While some steps are positive in this regards but yet they need the proper implementation plan and sustainability. European Commission, Kosovo Progress Report 2014 explains that Kosovo needs to actively work on its EU reform agenda and the priorities highlighted in the 2012 Feasibility Study and most recent Progress Reports. Under the SAA, Kosovo has committed to comprehensive reform and legislative alignment with the EU Acquis, including in sectors such as the rule of law, public administration, economy, competition and trade. Kosovo should focus on preparing the smooth implementation of the SAA including the necessary structures. ${ }^{5}$ As regards of political aspect, the new government and the Assembly will need to re-energise Kosovo's reform agenda. ${ }^{6}$ Therefore, the country mechanisms of law and politics must properly use recommendations given by the European Union and International mechanisms for ensuring rule of law enforcement and independence of

\footnotetext{
1 Edited by Jonathan Michie and John Grieve Smith. Global Instability The political economy of world economic governance. This edition published in the Taylor \& Francis e-Library, 2005. Pg. 29. For more see at: See also Sachs (1997); Stiglitz (1998a, 8b); Feldstein (1998a, 1998b); Wade and Veneroso (1998); Amsden and Euh (1997); Akyuz (1997).

2 Eric M. Uslaner .Corruption, Inequality and Rule of Law. Cambridge University Press. 2008. no. pg.

3 lbid. no. pg.

4European Commission. Kosovo Progress Report 2014. October 2014. pg.1. Available on: http://www.meiks.net/repository/docs/20141008-kosovo-progress-report_en.pdf [Accessed: 23 March 2015]

5 lbid.

6 lbid.
} 
judicial system as well as on fighting the corruption in order to create a safe and attractive business environment which will naturally lead toward access into globalization and make country sustainable.

\subsection{Economical Sustainability and free trade}

Kosovo thus far lacks on having sustained economic environment and favorable free trade conditions both for local and international business. Country until now faces a lot of unsolved internal issues which do not fit with global agenda of business, known as globalization. As regards the economic criteria, Kosovo made limited progress on its path to become a functioning market economy. Substantial efforts are needed to tackle structural weaknesses to cope with competitive pressures and market forces within the Union over the long term. Economic growth remained positive at $3.4 \%$ but did not yield any improvements in labor market conditions. High external imbalances persist despite some narrowing of the trade deficit. Macroeconomic stability was broadly preserved despite significant pre-election ad hoc increases in current expenditure, in particular on wages and pensions. Such practice deteriorates the transparency, predictability and credibility of fiscal policy, complicates fiscal planning and shifts the composition of spending towards less growth-friendly expenditure. Strengthening fiscal planning and effectively implementing the fiscal rule is vital. Moreover, decisions on large infrastructure projects, such as in the transport sector, should be based on proper cost-benefit evaluations to maximize economic benefits. In view of the persistent and very high unemployment, efforts should be undertaken to facilitate private-sector development through improvements in the business environment. To that end, obstacles arising from weak administrative capacities, difficult access to finance and lengthy and complex privatization procedures should be swiftly addressed. Kosovo must ensure a properly functioning legal and judiciary system, enhance contract enforcement and effectively reduce delays in courts. Economic statistics need to be improved. ${ }^{1}$

On the other hand, Kosovo did some small steps regarding bilateral relations with other enlargement countries, Kosovo has continued to have very good relations with Albania, with which it signed a declaration on cooperation and strategic partnership aiming to boost economic growth. Bilateral agreements were concluded in the areas of health, tourism, culture, taxation, use of joint border customs points, energy, unification of the employment market, the opening of joint consular offices, and on collaboration on the use of the EU acquis translated into Albanian. ${ }^{2}$ Yet the country lacks on having partnership strategic agreements even with few regional countries, such as the case of Bosnia and Herzegovina, due to its political aspect of non-recognition of the independence of Kosovo from this country. Similar pending issues are evident also with few other world countries, as Kosovo has not been recognized by many world countries. But, Kosovo has shown some positive trends on maintaining very close relations with Turkey. ${ }^{3}$ Even few positive trends of inclusion of Kosovo into globalization, yet the European Commission as regards of examining economic developments in Kosovo, the Commission's approach guided by the conclusions of the European Council in Copenhagen in June 1993, stated that membership of the Union requires the existence of a functioning market economy and the capacity to cope with competitive pressure and market forces within the Union. ${ }^{4}$ We consider that the country yet needs to overcome many internal unsolved difficulties, aforementioned.

\subsection{Economy prioritization}

Kosovo as a country has a low economy and the unemployment rate is high, and the chances for rapid change of this situation are weak. This due to the financial lack as well as other factors which are discussed in the paper. Kosovo's economic growth accelerated, but long term sustainable sources of growth are lacking. ${ }^{5}$ But, we consider that something that government needs to take care on this regards, is to seriously work on analyzing natural resources and possibilities for exploitation of them. Therefore, government must work on prioritizing the economy based on the analysis of its resources, and put its national strategy on inciting opening of private businesses on those areas. E.g. Kosovo has a great potential of agriculture development, tourism, etc. Priority areas would be a hope for people who are in their extreme poverty

\footnotetext{
1 lbid. pg. 4

2 lbid. pg. 23

3lbid. Pg. 24

4lbid. Pg. 24

5lbid. Pg. 25
} 
as well, by offering grants and assisting in human capital development. So far, few steps have been made by the respective ministry of Kosovo but yet they need to be planned in more strategic plan and corruption must not be part of this process. The selection of business ideas must be a long process, by helping people shape their ideas and maintain their businesses which will arise from the national prioritization of economy. Also, this process would have a positive impact on international area, where businesses might be interested to have their business operating in those areas. We believe that a generalized economy is not an economy which can be easily approachable either for domestic or international business. Therefore country must include prioritization of the economy as an urgent need and work toward accomplishing that aim, by thinking of employability, globalization and building an attractive business environment distinguished for specific aspects from other regional or international countries. E.g. for panoramic views, cultural heritage, social well-fare, agricultural zones, etc. Probably we shouldn't at this stage be to idealist by believing that we can bring Nokia here in Kosovo. Kosovo industry is probably not achievable at this point. But, the objective of the country must be oriented in that toward. That's exactly means the fundamentals of sustainable economy at the same time state sustainability.

\section{4 .}

\section{Inciting domestic production}

Kosovo governmental instruments must be focused more on developing country policy on supporting a domestic cement industry by supporting local producers achieve their international competitors. This policy is serving no useful economic objective (encouraging learning by doing, for example), its only role being to make transfers from the population at large (who ultimately consume cement) to the domestic cement industry. In addition, there is significant deadweight costs associated with the transfer: that is, the gains from the policy for the cement industry will be less than the cost to the rest of the economy. The World Bank has no desire for transfers to be made to the cement industry, and would like to induce the policy maker to eliminate the protection. The World Bank is considering offering grants, loans, etc. to the country, which would be to the policy maker's benefit ${ }^{1}$. Kosovo, despite improvements in the trade deficit, significant imbalances persisted, largely due to a weak production base ${ }^{2}$, therefore the country should put a focus on establishing mechanisms for domestic production incitements. One of the issues here is that of a registration process of businesses where, the country amid some progress in simplifying business registration, private sector development remains hampered by numerous obstacles. ${ }^{3}$

\subsection{Better linkage between academia and labor market}

The government should create proper mechanisms to better address the role of academia into analysis of the labor market. On the other hand, the labor market should better be linked to the academia, in order for the trends of business environment to be addressed by academic curriculum. We consider that this gap of communication creates a negative impact on getting prepared labor force that is skilled to adjust their academic knowledge into globalized labor skills.

The role of academic economists, in specific, must be also addressed while policy makers or governmental instruments on assisting on policy drafting and economic strategy of the country. An opinion about this issue is that academic economists typically respond to public and policy-maker concerns by explaining that, while there are adjustment costs in the short run, in the long run there are aggregate gains from freer trade. ${ }^{4}$

The report which concludes on the academia and its role on the economy is explained I in the following part of the Progress Report for Kosovo 2014, where it is clearly stated that the country due to "insufficient funding, the low level of cooperation

\footnotetext{
${ }^{1}$ Gustav Ranis, James Raymond Vreeland and Stephen Kosack, Ed. "Globalisation and the Nation State. The impact of the IMF and the World Bank". Routledge is an imprint of the Taylor \& Francis Group, 2006. pg. 37

2European Commission. "Kosovo Progress Report 2014". October 2014. Pg. 26. Available on: http://www.meiks.net/repository/docs/20141008-kosovo-progress-report en.pdf [Accessed: 23 March 2015].

3lbid. Pg. 28

4David Greenaway, Richard Upward and Peter Wright Ed. "Globalization and Labour Market Adjustment”. PALGRAVE MACMILLAN. 2008. pg 97
} 
between vocational schools and enterprises to conduct practical learning and delays in the implementation of policies to provide the skills required by the labor market remain as the major problems". 1

\subsection{Create a safe and appropriate environment for FDI's}

It is well known that FDI plays a potential role in encouraging and supporting a successful transition. FDI in transition economies appears to be an effective tool for several reasons such as transfer of knowledge, increased productivity, upgrading of managerial and labor force skills, improving the state balance, balancing deficits, accelerating privatization of state-owned enterprises and quickly restructuring of them. ${ }^{2}$ Therefore country needs to set proper mechanisms of ensuring international corporations that Kosovo is a safe place for investments. The reforms ought to happen immediately on economic, social and judicial aspect, so for these potential investors to feel safe for investing their capital in Kosovo, by increasing this way the GDP of the country and exposed toward international trade and international market.

Based on study done on this regard, the economic programme of transition involves the following four factors, but in no particular order. The first is macroeconomic stabilization, in order mainly to reduce inflation and to decrease the debt burden. The second is liberalization of economic activity such as prices, trade, currency convertibility, etc. The third is the reduction of the size of public sector by privatizing and restructuring state-owned enterprises. The last factor required introduction of new laws and regulations. For example, property rights, corporate law, accounting practices, tax regulation, etc. $^{3}$

Due to the existing international economic cooperation Kosovo has its right to use its own natural resources facing some limitations on fully enjoying the right of using its property and its national resources when it comes to the obligation stemming from international agreements on economic cooperation. The countries constitution in its article 122, paragraph 1 , stipulates "The people of the Republic of Kosovo may, in accordance with such reasonable conditions as may be established by law, enjoy the natural resources of the Republic of Kosovo, but they may not infringe on the obligations stemming from international agreements on economic cooperation"4. More than this, the following article says "Natural resources such as water, air space, mineral resources and other natural resources including land, flora and fauna, other parts of nature, immovable property and other goods of special cultural, historic, economic and ecologic importance, which have been determined by law to be of special interest to the Republic of Kosovo, shall enjoy special protection in accordance with law5. Whereas, "Limitations on owners' rights and other exploitation rights on goods of special interest to the Republic of Kosovo and the compensation for such limitations shall be provided by law"6.

\section{Inciting research and innovation by scholars and researchers ${ }^{7}$}

Scholars and researchers must be responsive toward modern needs for development. Due to the large scale of innovation in international aspect, they must quickly approach on the needs of highest standards for technological innovation, economy standards adoption, for law improvements, academic and other life-long learning capacity improvement. As regards of national innovation systems few concepts are presented which explain the great linkage and impact that scholars and

\footnotetext{
'European Commission. "Kosovo Progress Report 2014". October 2014. Pg. 27. Available on: http://www.meiks.net/repository/docs/20141008-kosovo-progress-report_en.pdf [Accessed: 23 March 2015].

${ }^{2}$ Aristidis Bitzenis. "The Balkans: Foreign Direct Investments and EU Accession". Ashgate 2009.

3lbid. pg. 4

${ }^{4}$ Constitution of the Republic of Kosova. Art 122, par. 1

5 lbid, par. 2

6lbid. par 3.

${ }^{7} \mathrm{~A}$ national system of innovation is the system of interacting private and public firms (either large or small), universities, and government agencies aiming at the production of science and technology within national borders. Interaction among these units may be technological, commercial, legal, social, and financial, in as much as the goal of the interaction is the development, protection, financing, or regulation of new science and technology. For more, see at: Niosi et al. 1993
} 
researches has with the country development, which is seen on Freeman who believes that the network of institutions in the public-private sector whose activities and interactions initiate, import, modify and diffuse new technologies ${ }^{1}$

\section{Adoption of international trade policy in Kosovo}

The focus of Freeman's unpublished OECD paper (1982) where the concept "national innovation system" appeared for the first time was on how countries could build knowledge and knowledge infrastructure at the national level with the aim to promote economic development and international competitiveness. A key reference to the paper was to Freidrich List (1842), and his concept "the national system of production". Freeman pointed out that List was concerned that applying Adam Smith's invisible hand and his "cosmopolitan" strategy would leave countries that were less developed than Great Britain permanently and increasingly behind. List pointed to the need for national governments to be active and build infrastructure and invest in knowledge. In this context he argued that the most important form of capital was neither physical nor financial- it was "mental"- today we would call it "intellectual". He also pointed to the need to protect "infant industries" until they could become strong enough to compete on equal terms with firms from England. ${ }^{2}$

International trade economists have long maintained that a liberal and outwardoriented trade regime is the best strategy for a small economy to increase its welfare and income by optimizing the allocation of its resources in production according to the country's comparative advantage, and by minimizing the incentives for unproductive activities associated with protection, such as smuggling, lobbying, and tariff evasion. ${ }^{3}$

\section{Conclusion}

The creation of the state does not imply political aspects lone. Parallel to political processes we have to go through the territory capabilities in the economic sphere as to enjoy and use the national resources. This process does not solely imply domestic rules and regulations as globalization refers to adoption and obeying to the international rules.

Kosovo as a new born country due to its fragile position even in the regional aspect faces true challenges on understanding and creating a climate of situating free international market. Although Kosovo's economy grew uninterruptedly since 2001 much of its growth can be attributed to the low base effects as genuine sources of sustainable growth remain absent. High and persistent external imbalances, somewhat mitigated by significant inflow of worker remittances, showcase a weak production base and lack of international competitiveness. Inefficient and heavily subsidized POEs, and ad hoc decision making, characterize Kosovo's public sector. Although measures such as the introduction of the fiscal rule were enacted, their reinforcement mechanisms remain weak. The labor market is characterized by low participation and high unemployment rates. Large shares of youth, long term and unskilled unemployed show deeply embedded structural rigidities. The widespread informal economy, weak rule of law and lack of fiscal predictability remain major obstacles to doing business and improving competition and productivity in the economy. Significant further efforts are needed to develop a competitive private sector and anchor fiscal sustainability. ${ }^{4}$ First country needs to undertake steps, in the direction of overcoming these challenges by working harder on rules and regulations as well as on national strategy that addresses properly the strategic agenda of the country and prioritizes the areas of development. This would help the proper national financial allocation as well as would help drafting laws and regulations which are suitable and feasible for the country. This would also lead FDls in the future, to possibly invest on these areas, rather than being generalized and not orienting properly, on where country is oriented as regards of investments. Therefore we consider that based on the analysis, country must undertake some concrete steps on building stronger communication with research academies, so to better understand the gaps and needs of the economy. This is proved also by the suggestions of European Commissions given to Kosovo where, among other is said that there has been very limited progress in the improvement of physical capital besides road

'Bengt-Ake Lundvall, Ed. "Handbook of Innovation Systems of Developing Countries. Building Domestic Capabilities in Global Setting". Published by Edward Elgar Publishing Limited 2009. Pg. 16

2lbid. pg 19

3lbid. pg 45

4 European Commission. Kosovo Progress Report 2014. October 2014. Pg. 24. Available on: http://www.meiks.net/repository/docs/20141008-kosovo-progress-report en.pdf [Accessed: 23 March 2015] 
infrastructure. Higher priority should be given to sectors such as education'1. This we believe that would be achieved by increasing the level of budget allocated for research and innovation. Country must work on strategies, by considering and using human resources such as scholars, academics, researchers and innovators, and youngsters which are able to use contemporary methodology, techniques and technologies and other instruments for proper research analysis of the economic situation and get the recommendations toward building the national economic area strategies. Through these resources, the country might assure the economic and political sustainability and increase the possibility for inclusiveness of international market trends into country.

\section{List of references}

[1] Aristidis Bitzenis. "The Balkans: Foreign Direct Investments and EU Accession”. Ashgate 2009.

[2] Bengt-Ake Lundvall, Ed. "Handbook of Innovation Systems of Developing Countries. Building Domestic Capabilities in Global Setting". Published by Edward Elgar Publishing Limited 2009; 2015 Index of Economic Freedom Brochure, March 2015. Available on: http://www.heritage.org/index/pdf/2015/countries/kosovo.pdf [Accessed: 21 March, 2015]

[3] Constitution of the Republic of Kosova. Art 122, par. 1;

[4] David Bigman, Ed. "Globalization and the developing countries. Emerging strategies for rural development and poverty alleviations". CABI publishing in association with the International Service for National Agricultural Research. 2002;

[5] David Greenaway, Richard Upward and Peter Wright Ed. "Globalisation and Labour Market Adjustment". PALGRAVE MACMILLAN. 2008;

[6] Edited by Jonathan Michie and John Grieve Smith. Global Instability The political economy of world economic governance;

[7] Eric M. Uslaner .Corruption, Inequality and Rule of Law. Cambridge University Press. 2008;

[8] European Commission. Kosovo Progress Report 2014. October 2014. Available on: http://www.meiks.net/repository/docs/20141008-kosovo-progress-report_en.pdf [Accessed: 23 March 2015];

[9] Gustav Ranis, James Raymond Vreeland and Stephen Kosack, Ed. "Globalisation and the Nation State. The impact of the IMF and the World Bank". Routledge is an imprint of the Taylor \& Francis Group, 2006;

[10] International Covenant on Civil and Political Rights;

[11] International Covenant on Economic, Social and Cultural Rights;

[12] The Economics of Sustainable Development, Sisay Afera, W.E. Upjohn Institute for Employment Research Kalamazoo, Michigan, 2005;

[13] Universal Declaration of Human Rights;

1 lbid. pg 29 